\title{
'Thinking' terminologies from Qurónic perspective and their impact on human intellectual development
}

\author{
Jamal Badi \\ Department of General Studies, \\ College of Human Sciences, \\ International Islamic University Malaysia, \\ Jalan Gombak, 53100 Kuala Lumpur, Malaysia \\ E-mail: Jama1956@gmail.com
}

\begin{abstract}
The 'Qur'Én' as a divine book has terms that are used and related to 'thinking' such as Tal̂awwur (conceiving), Idrak (perceiving), Fiqh (grasping), TaÑaqqul (reasoning), Tadhakkur (contemplating) etc. This paper explores major Qur'Énic terms related to thinking with the aim of uncovering potential value of these terms for human life. For this purpose, both textual and contextual analyses have been applied, as appropriate. The paper argues that internalising the Qur'Énic terms for thinking will contribute to the uplift of the global struggle on formalisation of thinking in public and private places for rightful human thought. The positive influence of Qur'Énic thinking will not remain limited to individuals, but will also affect communities through influence of human thought and behaviour which, in turn, will lead to a paradigm shift in the academic realm.
\end{abstract}

Keywords: thinking; Qur'Én terminologies; human intellect; development.

Reference to this paper should be made as follows: Badi, J. (2011) "Thinking' terminologies from Qurónic perspective and their impact on human intellectual development', Int. J. Arab Culture, Management and Sustainable Development, Vol. 2, No. 1, pp.41-54.

Biographical notes: Jamal Badi is an Associate Professor at the General Studies Department, Kulliyyah of Islamic Revealed Knowledge and Human Sciences, International Islamic University Malaysia.

\section{Introduction}

Man has been endowed with faculties that are necessary for him to carry out the responsibilities assigned to him by AllÉh. One of such faculties is thinking. It is this faculty of man that makes him essentially different from other creatures, including animals and angels. It is man's act of thinking that shapes and reshapes his life. His ability to think includes his ability to distinguish right from wrong. And thinking on the right lines makes his life praiseworthy; thinking on the wrong lines, on the other hand, makes his life blameworthy. Thus, one of the contemporary western thinkers Baron (2008) defined thinking as a method of finding and choosing among potential possibilities, i.e., possible actions, beliefs, or personal goals. 
The Qur'ān has, time and again, invited human kind to 'think' on every matter significant or insignificant, making use of several distinct terms that signify thinking. These include tafakkur, tadabbur, tadhakkur, tafaqquh, and ta'aqqul. These Qur'ānic terms do not usually carry the exactly same meanings; they signify related yet distinct modes of thinking. The application of these modes of thinking is likely to bring about great changes in human behaviour, sometimes positive when rightly applied and probably negative behaviour when wrongly applied. This paper is a humble attempt to highlight the meanings of certain Qur'ānic terms close to the import of thinking. A more significant contribution expected of this paper is the identification of potential application and impact of these terms in everyday life.

Baron (2008) had identified three modes that can be described in terms of a common framework of thinking; these are thinking about decisions, thinking about beliefs, and thinking about goals for one's life. In our view, belief is the bases of these means of thinking. This is where Qur'ān comes in as. It provides a sound ground of belief.

Despite the fact that Arabic language was spoken before Islam, the Prophet (peace be upon him) was the perfect interpreter of the verses and the vocabulary of the Qur'Én. Essentially, the traditions of the Prophet (peace be upon him) serves as a dictionary or an encyclopedia of the Qur'Én, where meanings and intentions of the Qur'Én are fully expressed. However, there remains much need for further scrutiny that is, the Islamic cognitive tool to explore, deliberate upon and extract new rulings in an attempt to relate and apply the Qur'Énic text to newly arising situations in everyday life. In order to scrutinise, the companions, early scholars, and contemporary scholars have had to use their sound reasoning so that the meanings and intentions of the Qur'ann could be extended to such situations as were not mentioned by the Prophet (peace be upon him). Therefore, in this paper, discussion on Qur'Enic contributions to intellectual development, followed by thinking terms as they appears in Qur'Én, and Qur'Énic taxonomy were explored.

\section{The role and contributions of the Qur'Én to intellectual development}

The section above indicates that AllÉh challenges man several times to think. This challenge is not in isolation or without being given some instructions that may seems signifies an insight on knowing the divine's position as to where and how such a thing could be acquire into the intellect. Thus, historical account has been the major form of intellectual reminder in the Qur'Én. The adoption of a given law and backup with a similar story which had occurred before or narrating a story which will lead to law or modification of law are almost three quarters of the Qur'Én. The reason for this is not difficult to understand; it is because human being is by nature forgetful. Based on frequent calling for thinking and reflection in the Qur'Én and, as well as elaborating and juxtaposing on similar antecedent are inevitable, and compelling in improving and enhancing the thinking of people of the message.

Reawakening through narrations by referring to physical objects which human beings can see, touch, and feel, and in order to reactivate their comprehension of the messages of the Qur'Én and as well generate knowledge such as the case of sons of Ódam (peace be upon him) which serves as message burial preparation. Additionally, the Qur'ān says, "And We have appointed the night and the day as two signs; then, We have made dark the sign of the night while We have made the sign of the day illuminating, ... and that 
you may know the number of years and the reckoning ... ". al-IsrÉ': 12. For we can see and perceive what is night and day, with further expression of the year, human beings have designed and deeper their expression of the uses of day and night. Similarly, concerning how deep-rooted mountains are, the Qur'Én expresses in al-Fûiliah: 9-12 that twice as much the top of a mountain is its root, which was more recently established by contemporary scientists ${ }^{1}$. These and many other examples have stimulated the thinking faculties and generated further knowledge for human being. In the field of modern biology 'Qur'En' expresses that, "bones were installed in the fetus before the complete formation of the flesh" al-Mu'minūn 14. This has been an interesting research area for biologists around the world and remains one of today's world wonders, however, search for method of installation of bone in flesh remains uncovered for modern scientists. However, through the accounts of these verses many facts about human being have emerged and developments have been made in standardising the life and, as well as curing, averting, and preventing hazards associated with human beings' health and living ${ }^{2}$.

With these examples and perhaps with many more, the importance of thinking in a linguistic form was established and relevance of the Qur'Enic terms concerning 'thinking' (such as tafakkur, tadabbur, tadhakkur, tafaqquh, taÑaqqul, etc.) cannot be overemphasised. In Qur'Én calls on "the unbelievers to have not seen that the sky and the earth were joined together before, that they were separated in order to shower water on them and AllÉh based all life on water [...]" al-AnbiyÉ': 30, is dramatic affirmation of the account given in the Qur'Én hundred years ago ${ }^{3}$. From this verse and others that are mentioned here affirmed authenticities of the Qur'Én's contribution to intellectual development. Furthermore, deliberation by modern scientific thinkers' such as meteorologists that came after this verse had led to the development of rain gauge and other weather-forecasting systems and instruments.

Additionally, modern scientist such as Maurice and others have proved beyond reasonable doubt the scientific knowledge grounded in the Qur'Én that were modern discoveries thousand year after. Many verses in the Qur'Én have served as stimulus for human kind in their thinking process. In Qur'Én 57: 25 the account that the iron is sent down from the heaven for the benefit of human kind has been described and affirmed by modern astronomical findings that iron found in our world comes from the giant stars in outer space, all these are challenges which stimulates further thinking and advancement of the human intellects ${ }^{4}$. Many accounts of self-assessment such as the movement of stars and sun, etc., affirmed by the modern physicists were given in the Qur'Én. The civilisation and intellectual development were arrived at after learning about previous generations; thus, the Qur'Én laid emphasis on reflection on the past events, in order for human beings to redesign and restructure their thinking system and every aspects of life which could lead to positive or negative result when used properly or improperly respectively. Specifically, in the Qur'Én, human beings - Muslims and non-Muslims alike - were encouraged to travel through the earth in order to explore and discover the divine laws governing the universe al-'AnkabËt 20, however, discussions always articulates to those with ability to reason.

Unconsciously, the English legal system, in 1886, negligence was defined, the key words in the definition were "doing something which a reasonable man would not do". The reasonability of a person rests on his/her level of thinking; effective respond to a particular situation without complicating the issue at stake. Likewise, AllÉh says in the Qur'ān, “[...] surely reminder of the message is for nobody except men of 
comprehension" al-RaÑd: 19. Comprehension cannot be attained without thinking and proper evaluation of an event or matter as the case may be, through comprehension of the language of communication.

In view of afore mentioned examples and discussions, it is reasonable to conclude that human intellectual development has drawn upon the words of AllÉh, for every scientific development has a trace in the Qur'Én; and it is known that Muhammad (peace and blessings be upon him) born and rise in the desert with formal teacher nor did any Jewish sage guided him to these pearls of knowledge. This justifies that the human kind will never exceed the finite level of their knowledge, for some of the notions in the Qur'Én (such as the soul, its arrival in and departure from the body) are presently beyond the reach of modern scientific knowledge.

The relevance of the Qur'Én in modern intellectual development as discussed above is not exhaustive, however, present focus will be on existing literature on 'thinking' in the light of the Qur'Én. This will be followed by thinking terms as they appeared in Qur'anic, which seems to be the first of its kind. Existing works have only mentioned and too often generalised the Qur'anic terms related to thinking; attention has not been given to relation between the terms and the forms in which they work and above all, taxonomy.

Of significance are al-Rāzì's views on thinking in the Qur'Énic context. Al-Imām al-Rāz $\hat{E}^{5}$, a prominent exegesis (mufassir), interpreted the word thinking and its synonyms as knowledge ${ }^{6}$, in his commentary on al-Baqarah 31, "And He taught Adam all the names". One may wonder about the link between knowledge and thinking from an Islamic perspective. Kamali elucidates:

\begin{abstract}
“The Qur'Énic vision of knowledge may be characterized as knowledge that is founded in understanding ( $\mathrm{fahm}$ ) and insight (tafaqquh). This is indicated in the numerous references in the text which encourage rational observation, thought, and reflection on the observable world and the universe beyond and in other words the creations of AllÉh. It is knowledge espoused with insight that the Qur'an has visualized in its expression al-tafaqquh fi'l-dinn, that is, understands the religion, signifying a rational and inquisitive approach to constructing a worldview of Islam. Islam, in other words, advises analytical knowledge and understanding that generate insight rather than a purely dogmatic approach.",
\end{abstract}

In Sayyid Qutb's view, knowledge comprises of three essential components: comprehension, interaction, and action. ${ }^{8} \mathrm{He}$ states, "Knowledge is complete comprehension, in the depths of soul and conscience, which is then followed by action in harmony with them". ${ }^{9}$ It is clear that comprehension or mere understanding of anything is not knowledge, but the beginning of it. Comprehension is followed by the second stage of interaction with what is comprehended. Interaction with what is comprehended is not something superficial and informal. Interaction is rather deep and must stimulate action. Thus, the whole process of knowledge is unthinkable without the three stages: comprehension, interaction with what is comprehended, and action. With comprehension alone, knowledge is inconclusive and incomplete. A very important point can be noted here: that action is not outside the realm of knowledge; instead, it is an essential ingredient of knowledge. Realisation of knowledge leads to action. ${ }^{10}$ This unity of thought and action implies the unity of soul and body. Comprehension and interaction with what is comprehended are done by the mind and the soul, and action is undertaken by the body. 
Ibn Taymiyah ${ }^{11}$ has also elaborated the relationship between the heart and actions of human beings. He affirms that physical actions of human beings are the reflection of internal cognition. Contemplation is a stage where knowledge begins and subsequently results in the genesis of either verbal or physical actions. This internal cognition may have positive or negative impact on the heart, which can develop into permanent behaviour and attitude. Thus, behaviour is the reflection of what the heart is nurtured on; if the heart nurtured on good and the good is acted upon it becomes rewarding, as in the form of ' $i b E^{\prime} d a h$, otherwise it may be on the wrong which will result in punishment ${ }^{12}$.

It is crystal clear that ' $i b E ́ E d a h$ is a knowledge-based notion and practise in Islam. According to MÉlik BadrÊ, a Muslim is considered to have fulfilled his obligation and 'ibÉdah by thinking. Thus, his motivation to know the greatness of his God's creation is naturally greater than the motivation of others. ${ }^{13}$ The Qur'Én says "Among His servants, those who have knowledge truly fear AllÉh". (Fātir 28) In outward nature, through colour for example, we can understand and appreciate the finest shades and gradation. But in the spiritual world the variation and gradation are even more subtle and comprehensive. Who can truly understand them? Only those endowed with knowledge, i.e., those who have inner knowledge which comes through their acquaintance with the spiritual world; it is such people who truly appreciate the inner world, and it is they who know that the fear of God is the beginning of knowledge and wisdom, for such fear is akin to appreciation and love - appreciation of all the marvellous beauties of AllÉh's outer and inner world ('Allah is Exalted in Might') and love for His grace and kindness ('Oft-Forgiving'). But AllÉh's forgiveness extends to even those who do not truly understand Him ${ }^{14}$. This inner knowledge based on tadhakkur leads to physical knowledge and appreciation of AllÉh's creatures.

Baron, a contemporary western thinker and psychologist considers beliefs the major source of thinking. Beliefs, in turn, depend on knowledge; if one's knowledge and beliefs do not correspond with reality, one's thinking is off the mark. Accordingly, inference laid much emphasis on two main sources - the internal source, i.e., memory, and the external written sources. ${ }^{15}$ Applying this to our discourse, it implies that human beings were endowed with some knowledge even before Islam, but with the Qur'Énic text, all ambiguities were cleared; as Baron concluded that the external sources, that is, information helps the internal source in order to achieve its goals or complete the task of thinking.

It is worth emphasising here that the term tafakkur (thinking) is a Qur'Énic term in its own right and is not synonymous with knowledge. Of course, there are other terms that are distinct in function, but work as a chain of events such as insight (tabaîtur), pondering (tadabbur), grasping (tafaqquh), taking to heart (tadhakkur), taking a lesson (i'tibÉr), using one's mind in the right way or reasoning (ta'aqqul), ${ }^{16}$ but the term tafakkur has been mentioned in the Qur'Én eighteen times. In all verses in which it occurs, it is used as a verb and not as a noun, i.e., as a process and not an abstract conception. $^{17}$

\section{The terminologies concerning 'thinking' as appeared Qur'ān}

As evident in previous discussions, the Qur'änic terms for thinking are akin to 'ilm (knowledge). As al-RÉzÊE and other scholars have dealt with the Qur'Énic terms of thinking, one may note that there are mainly two categories of such terms: terms treated 
with a linguistic approach; terms linked to logic. In the following pages, each of these categories will be discussed.

The Arabs before Islam were regarded as very eloquent. However, the uniqueness of the Qur'ānic language and terminology that characterised the word of AllÉh caught them in a surprise, and surpassed their long established badoins' literature. Thus, followings are some of the terms with linguistic and logical approaches as used in the Qur'Én in relation to creative thinking and problem solving:

- Tafkir (thought): Is an abstract notion which was coined out of 'fakar' (think), however, tafakkur (thinking) is a deliberate and systematic process of reflection. That is why the Qur'Én refers to it on multiple occasions and not just once. ${ }^{18}$ Moreover, out of its eighteen occurrences, on seventeen occasions, tafakkur has appeared in the Qur'an in present tense and its subject is the second or third person in plural, which denotes the importance of collective thinking in Islam. We might call this collective approach as "shËrÉtic (consultative) way of thinking". ${ }^{19}$ Here, one may also suggest the practise of collective ijtihād and ift $\bar{a}$.

- Tadhakkur (remembering): 'dhikir' which appears in the Qur'Én 292 forms and 107 derivative roots such as 'Tadhakkar' 1, 'TatadhakkarËn' 3, 'Waliyatadhakar' 1, 'Yatadhakkar' 7 times, etc. This appearance signifies the remembrance is for those who are of sound mind and wisdom. Some of these are "[...] surely He often reminds the wise" al-RaÑd: 19. Likewise, another verse says "Remember when you are small number weak on earth you afraid of oppression from people [...]" al-'AnfÉl: 26 the exegeses of Qur'Én unanimously agreed that the controlling verb 'Wadhkur $\ddot{E}$ ' (remember) in this verse refers to intellectual exercise not mouth. Furthermore, it signifies recalling as an abstract knowledge and as a vital tool of thinking. Additionally, the Qur'Én states the model of knowledge generation from remembrance to clear seeing "Surely those who fear (AllÉh) whenever some evil group victimise them they remember thereafter they sight/see" al-AÑrÉf: 201. Thinking process begins whenever events or an event brings one to react, create, and innovate at any point in time regardless of geographical and personality respectively. The end product of the intellectual exercise is an insight to the situation at large.

- Tabâ̂̂िur (insight): Originated from 'BaÎar' which appears in Qur'Én in 148 forms

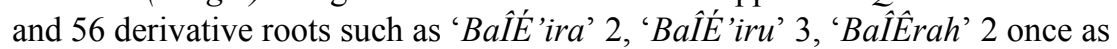
object and other as genitive or word governed by preposition, etc., in some of these forms their contextual meaning shows inner knowledge directed to the heart. A direct connection between 'Tadhakkur' and 'Tabâ̂̂Tur' is evident in al- AÑrÉf: 201 as quoted above. It shows that some trigger before insight outer sight receives messages, i.e., transmission from mind to eyes. For example $Q u r$ 'É $n$ says “ '[...] this is an insight from your Lord [...]" al-AÑrÉf: 203, which mean AllÉh has bestowed on human kinds inner eyes for seeing and perceiving the truth. Similarly, another verse says "This is vision for humankinds [...]" al-JÉthiyah: 20. Accordingly, "Say this is my way in which I called to the part of AllÉh on discernment for me and one who follow me [...]" YËsuf: 108. This could explain the shortest distance that exists between thinking organs.

- Fiqh (grasping): This term mentioned in Qur'Én 20 forms and 6 derivative roots means taking hold of something, but its root is from the word 'faqiha' which means to understand, know, etc. One of the significances of this word on knowledge and 
thinking is explained in al-Tawbah: 122 which Says "Why all the believers setting out for JihÉd (spread of Islam) would there be part of them that remain with the Prophet (p.b.u.h) and understand Islam in depth so that they may return and remind their people to be careful". It is crystal clear that the Companions know Islam very well by chosen to be one of those that spread Islam. Partly, because of the preceding verse: 120 that challenged the Medinites and their surroundings of turning away from Prophet. However, in order to clear the ambiguity between knowing and understanding, AllÉh orders some of these companions to stay at home learn and understand Islam in totality so that they may return to the new entrant to Islam and teach them Islam. In other words, AllÉh divided companions into two groups, those who go on $J i h E d$ and those who stay and understand the religion so that ammunition $j i h E ́ d$ is immediately followed by intellectual $j i h E d$. Accordingly, it explains the next step of action after 'tadhakur' (remembrance), and 'tabal̂̂ur' (inner sight) that is 'fiqh' understanding the real lessons, meanings, benefits, and dangers that would serve as clues to solutions. Additionally, the Qur'Én says “[...] what is wrong with this generation that could not be able to understand discussion" al-NisÉ':78. Again, It says "[...] see the manner We have execute the signs so that they may understand" al-ÑnÉm: 65.

Add to this, al-KhaÊb al-BaghdÉdÊ has stated that fiqh precedes hikmah (wisdom). The Prophet (peace be upon him) had described al-faqīh (the jurist) as a well of water from which people fetch water and fill their bottles. The role of this term as a vital tool of creativity and problem solving as stated in the Qur'Én and backed up by the tradition of the Prophet (peace be upon him) cannot be overemphasised. ${ }^{20}$

- Ta'aqqul (reasoning): The term originated from the verb 'Ñqal'. Literarily, it means 'reasoning'. It appears in Qur'Én 49 forms and 5 derivative roots such as 'TaÑqilËn' 24 times, 'YaÑqil̈̈n 22 times, and 'ÑUquluhu', 'NaÑqul', 'YaÑqiluhÉ' 1 time respectively. The significances of this term in thinking system are elucidates in Qur'Én "Is there swear in that for those that has brain" al-Fajr: 5, commentators of Qur'Én are unanimous that the word ' $\times$ ijr' means mind, intellect, brain, and reason because its subject matter lies on thinking and understanding of what next to come or do. In most cases this term is often use in Qur'Én to awakening the need to reason with existing and concrete facts. Example of this is "Uffi (woe) to you and your dirty gods that you worship aside AllÉh if you are not reasonable" al-AnbiyÉ': 67. Additionally, "Say (MuÍammad) come KuffÉr (unbelievers) I remind you what AllÉh has forbidden on you [...] if you are reasoning" al-AnÑÉm: 151. This listed five clear evidences for the disbelievers to pound on it, that, it never in wishes of AllÉh to punish you but you need to do away from the five major sins if you are wise. It is obvious that rational thinking to attain to in-depth knowledge is not only permissible but also encouraged in Islam. The principle beliefs and obligatory practises belong to this category where the human mind is allowed to explore the reasons and the facts of the matter, but to the mind's limitations just as any other human faculty.

- Idrak (perceiving): Derived from the verb 'Darak' which means to realise, perceive, recognise, and know. This word appears in Qur'Én in 12 forms and 12 derivative roots such as AdrÉka, Ódaraka, AddÉrakË, al-Darki which refers to bottom of hell fire. Those of the places that relates to thinking or realisation of knowledge are 
inform of direct question to the people in question such as "And what will make you know what the striking hour is?" al-QÉri'ah: 2. The Qur'ān has put across questions to the Prophet (peace be upon him) in such verses as "impliedly, the question here is to probe the source of knowledge of the prophet; thus, perceiving is a method of probing to know; what is the source of the particular matter by deep reflection? Similarly, "[...] until he realized he is going to perish [...]" YËnus: 90. Likewise, "[...] rather they will attain their knowledge in hereafter which they were in doubt in this world [...]" al-Naml: 66. These verses reflect the various methods of realisation adopted in the Qur'Én:

1 Realisation during life time as knowledge like in the case of Prophet (p.b.u.h) and as a caveat for repentance as called for reasoning and recognition of undisputable evidences put forward by AllÉh.

2 Realisation when there is no way to repent. During this period truth will be presented immediately before and after death such in the case of FirÑun not until when he saw death in reality then claims to know the truth. In addition, the last verse shows that some people will never realise until the day of resurrection. Yet a message of challenging the brain to strive to realise these evidences presented by AllÉh.

Therefore, it signifies the importance of life happening in realisation. Mostly, when realisation comes there will always be a result either physical or abstract to clarify ambiguity on subject matter in question.

- Tadabbur (pondering): It is a term derived from the verb 'Dabbara' which means to procure, obtain, get, and secure. It appears in Qur'Én in 21 forms and 44 derivative roots such as 'Yatadbbar' 4, and plural form 'YatadabbarËn' 2, etc. For those that relates to thinking and knowledge calls for procurement of the Qur'Én and pondering on its contents, arrangement and knowledge derived from its stories. Its contents to life reality, partly, serve as scientific method and process of creativity. To justify the uniqueness of facts in the Qur'Én, It Says "Have you not pondered on the Qur'an (contents) were it be from person other than AllÉh it would have contain many contradictions" al-NisÉ': 82. It signifies the vital role of pondering after acquisitions of facts or knowledge. Thus, have known something does not portray the real understanding of its contents. The similitude of this is holding to a scientific book at library or shelf does not affirm deep understanding or total procurement of both hard and soft substances of the book. Similarly, "The Book revealed unto thee (Prophet) full of blessings so that they may ponder on its messages/signs that shall be remembrance for the wise" ØÉd: 29 . This verse further clarifies earlier explanation that when an abstract knowledge is transformed to physical knowledge like signs and others there is need for securing period about the signs and messages itself to fully benefit from the peak of knowledge.

- Discussion: In Webster's dictionary, the word 'Reasoning' means thinking coherently and logically, drawing inferences or conclusion from the facts known or assumed, and arguing or talking in a logical way. This word has many synonyms, such as deducing, establishing, proving, inferring. ${ }^{21}$

The word ta'aqqul and its derivatives have been mentioned in the Qur'ān 49 times. $^{22}$ 'Aql (intellect) from which the word ta'aqqul (reasoning) is derived denotes mostly 
the ability to receive knowledge. Likewise, it also means fastening a camel with a shackle. ${ }^{23}$ The human intellect is called 'aql in Arabic because it binds the information grasped.

Qur'Énic terms have their own interpretation that transcends logic. For example, the Qur'ānic term ta'aqqul (reasoning) is very different from the Greek philosophical perspective on reasoning which tends to use abstract reasoning, a kind of rational analysis concepts, in order to build a philosophical system, which appears to them to be theoretically convincing. However, Qur'anic reasoning combines theory and inevitable facts, above all, makes them act according to the truth such as the case of Pharaoh's realisation of truth at drowning stage, the cadaver of Pharaoh yet remains as physical example as promised by the All Mighty in the Qur'Én. This a great wisdom established by All Mighty to awaking human kinds to reasoning.

Kamali attributes Qur'Énic wisdom in the following way: "Good judgment, insight, balance and avoidance of extremes, the ability to distinguish between truth and falsehood, and procedural accuracy are commonly associated with Iikmah (wisdom) and Iikmah as such becomes a dimension of evaluative thinking in its Qur'Énic idiom". ${ }^{24}$

\section{Establishing the Qur'Énic thinking taxonomy}

Having explored the Qur'Énic thinking terminologies, and examined their meaning, it is crystal clear that these terminologies reflect different levels of meanings. A question that comes to mind is: in what way they are inter-related? The answer to this question could be put into a form of Qur'Énic thinking taxonomy. Below is the diagram of the cognition followed by discussion to illustrate and establish the relationships between these terminologies.

Figure 1 The Qur'Énic thinking taxonomy

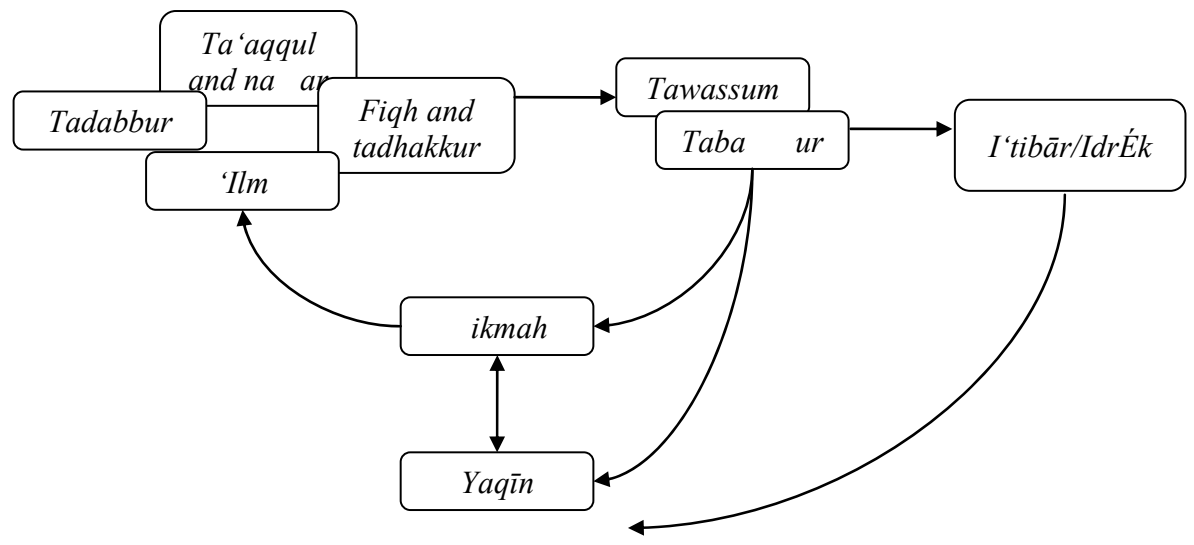

The above diagram is the system in which Qur'Én has described the four processes which human intellect do reach the true knowledge. The diagram displayed little or no hierarchy in thinking process as a continuous process with uninterrupted chain. Due to the nature of human brain; these processes take place almost at interval less than a 
second, which justify the occurrence of their action at relative time. The process is divided into four where every part is as important as others. The first part consists of four terms which TaÑqqul, Taddabur, Fiqh, Tadhakur which represent trapping stage of ÑIlm (knowledge) before refining. The second part termed refining stage is Tabassur in order to create a picture which is the second phase of the process. The third is IÑtbÉr practical application of knowledge. Lastly, YakÊn is the reward and result for practical application and $\times$ ikmah is the accumulation and further spread of the knowledge beyond expected result and new knowledge is generated. As we have discussed these thinking terminologies in the previous section, the thinking process begins from:

$T a \tilde{N} q q u l$ which is thinking tool based on deduction and observation. It is referred to in the Qur'Én as the standard of measuring and qualifying people whose thinking is apply. Thus, the imbeciles, ill mental and minors were excluded from retribution on their deeds during this period. The Qur'Én clearly states that its messages addresses those with complete sense which makes thinking possible. The observation here can be possibilities and/hypothesis and asking the question 'why' at the beginning of the thinking process which opens way for other terms to perform their roles. Gwynne ${ }^{25}$ ascertained that all words and linguistic concepts are used according to rules (or microrules) are prerequisite for communication. Then it necessitate Taddabur (pounding) which is inquisitive thinking into universe, its contents and Qur'Én. Through these two steps occurring almost simultaneously N Nlm true knowledge is reached through the combination of revelation, senses and reason. This action extends to Tadhakur frequent toasting of the idea on mind and Fiqh, i.e., deep understanding an effort to expand the NIIlm either to innovate or create.

Second stage which comprises of Tabâ̂̂िur which is perceptual application leading to creation of shape or design in which the knowledge could be practically applied. The result of this practical application or where one develops a rationale for any action or deeds that leads one to the fourth stage which is YakEn with its grammatical expression is the highest level of the truth about NIIm (knowledge). In other words, is the reality or live show which brings about confidence about the form, and nature of particular knowledge at hand; finally, followed by wisdom that manifests as a result of long or short-runs of mind engaged; from the Íikmah, i.e., wisdom transformation of ÑIlm into new dimension sets-in. In other words, a new system sets in either in an advanced level or new creativity may surface. An example is the discovery of transportation systems which advances through ages and stages from foot, animals such as horses, camels, etc., bicycle, bus, car, ship and aircraft as the highest, easiest and fastest.

The Human brain generates information uninterruptedly and in an irregular form; in the form Brownian Movement Theory ${ }^{26}$ has been described. Their uninterrupted manner is that after deduction and observation occur information are generate in various forms such as irregular or in an unarranged manner mixture of positive and negative ideas. Surely, a sort of knowledge has been acquire but needs more time to be processed or pass cognitive test. For proper arrangement comes in after cognitive and perceptional applications takes place followed by empirical or practical test. Deeper deliberation is engaged which will finally result in specific and akin to accurate knowledge.

No terminology can work in isolation or stages rather it works simultaneously. In other word, these actions take place almost at the same time. That is why, it will be inappropriate to separate between the terms as displayed above, thus, actions usually occur at the same time. This in contrast with bloom taxonomy that contended the hierarchy of thinking terms in stages. Additionally, this process is not static mostly a 
particular process is designed by the circumstance that call for the thinking. Background knowledge plays an important role in all knowledge generation.

Knowledge can be one acquires through pounding on AllÉh's creatures through Qur'Énic and Sunnatic ${ }^{27}$ (covenant) insight. The process of integration and harmonisation between the universe and social life is classified in the form of 3 by 3 which is explained as follows: The relationship between the universe and social life demands the integration and harmonisation between revelation, science and reason which is intended to unify between sects that totally rely on revelation, science only, and reason only. Another complex unification is the harmonisation of these three, i.e., revelation, science and reason with the mind, heart and the soul these three systems extend the process of the first set in order to yield new stage of knowledge. Furthermore, an abstract action which does need to complement this process is the integration and harmonisation between intellect, emotion, and the spiritual aspect of thinking.

Furthermore, it can be in a natural form of knowledge which is known as divine knowledge such as WaÍyu (revelation), and IlhÉm. The knowledge receive through Wahyu is specifically for the prophets while Prophet Muhammad (peace be upon him) is the seal of the prophets, the door of Wahyyu had been closed since the demised of the Prophet. However, the $I l h E ́ m$ are additional means which AllÉh does communicate with the prophets but extends the same benefit to the pious ones. Thus, one might acquire knowledge through dream or inspiration which is base on the integration and harmonisation between the mind, heart and the soul.

Therefore, neither the knowledge derived from revelation nor the knowledge from inspiration and dreams works in isolation rather they complement one another. Ultimately, the best is to unify these parts of thinking without discrimination of any part. Pertinently, there exists hierarchy between the sources of knowledge such as the NaĐar and TaÑqqul should start from the revelation either Qur'Én or Sunnah then proceeds to science or reason as the case may be. The 3 by 3 formula that we mentioned above must present in sources and thinking process before a meaningful and beneficial solution, innovation or creativity and creative behaviour can be achieved.

\section{Conclusions}

Thinking is a boon to human life. The act of thinking has various shapes and dimensions. The Qur'Én has used various terms for thinking such as tafakkur, tadhakkur, taddabbur, etc. Every term has its own precise connotation and application. These terms also refer in a very subtle manner to the principles of thinking. If understood and applied these terms practically, great positive impacts will appear in the life of the applicants. The principles that ensure safety of man from harms of thinking have been explained in the Qur'an.

Thinking based on and guided by Qur'Énic perspective can bring about substantial development to the human intellectuality.

\section{Acknowledgements}

I gratefully acknowledge the International Islamic University Malaysia's Research Management Centre (RMC) as the sole funder of this project. 


\section{References}

Abdul BÉqi, Muhammad FËad (1988) Mu’jam Mufahras Li Alfadzil Qur'an Al-Kariim, DÉr al $\times$ adith, Cairo.

AhmÉd MouÎallÊ (1990) 'Sayyid Qutb's view of knowledge', The American Journal of Islamic Social Sciences, Vol. 7, p.3.

Al RazÊ, Mohammad Bin Omar (1981) Al Tafs $\hat{E} r$ Al Kabt̂tr, 1st ed., Vol. 2, pp.222-226, DÉr al-Fikr, Beirut.

Al-BaghdÉdÊ, Al-KhatÊb (1980) Al-FaqÊh wal Al-mutafaqqih, 2nd ed., DÉr al Kutub 'ilmiyyah, Beirut.

Badi, J. and Tajdin, M. (2005) Creative Thinking An Islamic Perspective, pp.3-7, IIUM Research Management Centre, Kuala Lumpur.

Badri, D.R.M. (1993) Al Tafakkur Min al MushÉhadah Ila Al ShuhËd, 3rd ed., IIIT, Herndon.

Baron, J. (2008) Thinking and Deciding, 4th ed., Cambridge University Press, London.

Bucaille M. (1995) The Qur'Én and Modern Science, edited by Philiips A.A.B. (Eds.) available at http://www.sultan.org/articles/QScience.html (accessed on 8 June 2010); Yahyah, H. (2004) The Qur'an Lead the Way to Science.

Eistein, A. (1956) Investigations on the Theory of the Brownian Movement, Cowper, A.D. (transl.), R. 4th ed., Dover Publication Inc., New York.

Gwynne, R.W. (2004) Logic, Rhetoric and Legal in the Qur'Én: God's Arguments, Routledge and Taylor \& Francis Group, New York and Curzon.

Ibn Taymiyyah (2005) MajmËÑ al-FatÉwÉ, in AnwÉr al-BÉz and ÑÓmir al-JazÉr, 3rd eds., Vol. 10, p.98, DÉr al-WifÉ'.

Kamali, M.H. (2006) Reading the Signs: A Qur'anic Perspective on Thinking, Winter, Islam \& Science.

Øafi, LË'ayy (1994) The Challenge of Modernity: The Quest for Authenticity in the Arab World University Press of America, Maryland.

ØÉfi, LË'ayy (1998) 'ImaalAl Aql, DÉr al Fikr, Damascus.

Qutb, Sayyid (1974) Fi al-Tarikh, Fikrah wa minhÉj, Daar ShurËq, Cairo.

Qutb, Sayyid, (1979) In the Shade of The Qur'Én, Vol. 30, translated by M. Adil Salahi and Ashur A. Shamis, MWH London Publisher, London.

Webster, N. (1983) Webster New twentieth Century Dictionary, 2nd ed., Prentice Hall Press, New York.

Yahya, H. (2010) The Miracles of the Qur'Én, available at http://www.harunyahya.com/presentation/miraclesofthequran/index.html (accessed on 9 June 2010).

\section{Websites}

http://lwww.ouaysafi.com/content/view9/37/.

http://www.spiritus-temporis.com/ahmed-ibn-sahl-al-balkhi/.

http://www.absoluteastronomy.com/topics/Ahmed_ibn_Sahl_al-Balkhi.

\section{Notes}

1 Bucaille M. (1995) The Qur'Én and Modern Science, edited by Philiips A.A.B. (Eds.) available at http://www.sultan.org/articles/QScience.html (accessed on 8 June 2010); Yahyah, H. (2004) The Qur'an Lead the Way to Science. 
2 Ibid.

3 Ibid.

4 Yahya, H. (2010) The Miracles of the Qur'Én, available at http://www.harunyahya.com/presentation/miraclesofthequran/index.html (accessed on 9 June 2010).

5 AbË 'AbdullÉh Muhammad Ibn'Umar Ibn al-×asan Ibn al-×usayn al-TaymÊ al-RāzÊ, commonly known as Fakhr al-DÊn, was born at al-Rayy and lived between 544H/1150CE and $606 \mathrm{H} / 1210 \mathrm{CE}$. He was a famous scholar who received education from various scholars including his father. He specialised in $\operatorname{taf} \hat{s} \hat{E} r$ (exegesis), 'ilm al-kalÉm (theology), philosophy, etc. He wrote quite a number of books. One of his famous works is his tafsir which is commonly used by the Mu'tazilah; it is a rationalistic tafsìr of the Qur'Én.

6 Al RazÊE, Mohammad Bin Omar (1981) Al Tafs $\hat{E} r$ Al KabÊE, 1st ed., Vol. 2, pp.222-226, DÉr al-Fikr, Beirut.

7 Kamali, M.H. (2006) Reading the Signs: A Qur'anic Perspective on Thinking, Winter, Islam \& Science.

8 Sayyid Qutb IbrÉhÊm ×usayn al-ShÉribÊ (1324-1385H/1906-1966CE), an Egyptian Islamic thinker, learned at early age and joined the teachers' training college in Cairo. Later joined DÉr al-ÑUlËm and graduated 1933/1352H. Attached to the Ministry of Education and was sent to USA for further study and returned 1950/1370H. In 1950, he joined the JamaÑah al-IkhwÉn al-MuslimÊn 'The Muslim Brotherhood' which was later banned in 1966.

9 Qutub, S. (1974) Fi al-Tarikh, Fikrah wa minhaj, DÉr ShurËq, Cairo, quoted by Ahmad MouÎllÊ (1990) 'Sayyid Qutub's view of knowledge', The American Journal of Islamic Social Sciences, Vol. 7, No. 3, p.318.

10 We can consider a tertiary institution student in the hostel takes no action to move about only to relax in the room but whenever it occurs to him that there is fixed class, i.e., knowledge comes in he/she will act on the knowledge by dressing up and going to the class.

11 TaqÊ al-DÊn AbË al-'AbbÉs AÍmad Ibn 'Abd al-×alÊm Ibn 'Abd al-SalÉm Ibn 'AbdillÉh AbÊ al-QÉsim Ibn MuÍammad Ibn Taymiyah al-DamishqÊ, a popular scholar of the mid 11th Century to early 12th Century (1263-1328). A great Islamic thinker, philosopher, theologian, and well verse in Islamic sciences. Born in ×irÉn in Turkey moved away from war zone in xirÉn and seek refuge in Damascus with his family. Learned from his father, and other eminent Islamic scholars, well verse in science of Sunnah of the Prophet (p.b.u.h) which led him to be commemorated as ImÉm in knowledge and practices $720 \mathrm{H}[\ldots]$.

12 Ibn Taymiyyah (2005) MajmËÑ al-FatÉwÉ, in AnwÉr al-BÉz and ÑÓmir al-JazÉr, 3rd eds., Vol. 10, p.98, DÉr al-WifÉ'.

13 Badri, M. (1993) Al-Tafakkur min al-MushÉhadah ilá al-ShuhËd, 3rd ed., p.108, IIIT, Herndon.

14 Øurah al-Fä̈ir 28, The Holy Qur'Én: English Translation of the Meaning and Commentary, the Presidency of Islamic Researches, IFTA, p.1307.

15 Baron J. (2008) Thinking and Deciding, 4th ed., pp.12-16, Cambridge University Press, London.

16 Badi and Tajdin (2005) Creative Thinking an Islamic Perspective, pp.3-7.

17 Ibid. p.3, see p.2 the meaning of fikr, tafkir and Tafakkur.

18 Ibid. p. 2

19 Ibid. p. 3

20 See Al-KhaÊb al-BaghdÉdÊ. Al-FaqÊh wa al-Mutafaqqih, Vol. 1, pp.96, 122 and 196.

21 Webster, N. (1983) Webster New Twentieth Century Dictionary, p.1502.

22 Abdul baqi, Muhammad Fuad (1988) Mu'jam Al Mufahras Li Alfadz al Qur'Én Al-KarÊm, pp.468-469.

23 Ibid, p.577-579. 
24 Kamali, M. (2006) Reading the Signs: A Qur'anic Perspective on Thinking, Winter, Islam \& Science.

25 Gwynne, R.W. (2004) Logic, Rhetoric and Legal in the Qur'Én: God's Arguments, Routledge and Taylor \& Francis Group, New York and Curzon.

26 Eistein, A. (1956) Investigations on the Theory of the Brownian Movement, Cowper, A.D. (transl.), edited by Furth, R., Dover Publication Inc., New York.

27 Sunnatic is defined as the divine law governing the universe and the social life. 